\title{
Humanistic Learning of Social Studies at Junior High School of Budi Mulia 2 Yogyakarta Indonesia
}

\author{
Sudrajat $^{1, *}$, Supardi $^{1} \&$ Yuhanida Milhani ${ }^{1}$ \\ ${ }^{1}$ Universitas Negeri Yogyakarta, Indonesia \\ *Correspondence: Universitas Negeri Yogyakarta, Indonesia. E-mail: sudrajat@uny.ac.id
}

Received: December 17, 2019 Accepted: January 14, 2020 Published: February 14, 2020

doi:10.5296/ije.v12i1.16066 URL: https://doi.org/10.5296/ije.v12i1.16066

\begin{abstract}
The humanistic learning was done by emphasizing student-centered learning on natural and social phenomena. Unfortunately, only a few schools can realize humanist learning due to a variety of reasons and considerations. Budi Mulia 2 is one of the schools in Yogyakarta, Indonesia that realize humanistic social studies learning by providing a wide opportunity for students to seek information and reconstruct knowledge independently. The research aims to investigate the implementation of humanistic learning at junior high school in district of Yogyakarta, Indonesia. The study was directing the survey method with sample of 63 students of $8^{\text {th }}$ grade. Sample selection done by purposive sampling, because the social studies learning in its class carried out by humanists. Data analysis techniques were carried out with descriptive statistics to find the central tendency. The humanistic social studies learning at Budi Mulia 2 supported by the school's vision and mission which view each individual as a unique personality. In that context, teachers use learning methods that place students as the subjects, thus allowing them to learn, explore and seek information independently. In general, Budi Mulia 2 students feel that the school has provided adequate facilities to support their learning activities. Teachers have given serious attention by providing support, motivation, and serving the students as well as possible.
\end{abstract}

Keyword: humanistic learning, social studies, Budi Mulia 2 Yogyakarta Indonesia 


\section{Introduction}

Education was an attempt of restoring human function to avoid various forms of oppression, ignorance, and backwardness, processes of personality formation and human development as an individual, social, moral, and religious being. Hidayat \& Patras reported that the ability of human resources is strongly influenced by the processes and outcomes of education. To develop high-quality human resources, high quality process and implementation of education are also necessary (Sukendar, Usman \& Jabar, 2019). National education aims to develop learners' potentials so that they become human beings who believed and are cautious to God Almighty, have a noble, healthy, knowledgeable, capable, creative, independent, and become of democratic and responsible citizens (Indonesia Educational System Act No. 20, the Year 2003). Education demands people to live by following moral rules, in regards to the humans nature as moral beings.

In this case, culture has an important role as a process for overcoming animal characters. Humanization was an attempt to transcend other biological organisms and build upon it something unequal, creative, and enriching in a person. An independent human is a creative person in which culture revealed in their life. Education guides all the forces of nature that exist in children so that as human beings and as members of society, they can achieve the ultimate salvation and happiness to promote the values and the mind (Dewantara, 2004, p. 20). Meanwhile, other researchers view that education as an indistinguishable intellectual activity which represents human's efforts to develop knowledge. Education is an effort to create and cultivate human intellects that can awaken the human itself in determining the choices that reflect the full human personality (Muhmidayeli, 2011; Purwanto, 2009; Knight, 2007). People do not become a society by living in physical proximity, any more than a man caught by socially influenced by being so many feet or miles removed from others. A book or a letter may institute a more intimate association between human beings and the dwellers under the same roof. Individuals do not even compose a social group because they all work for a common end (Dewey, 1964, p. 3).

Educational processes integrated the transmission of cultural values in daily activity. All education is, in a sense, value education. Value-less or value-neutral education is a contradiction in terms, given the meaning of 'value' and 'education'. Education is a process of bringing about 'desirable' changes in the way one thinks, feels and acts by following one's concept of the good life. In this sense, education necessarily involves the transmission of values. Education should develop young people into fully integrated human beings with their values, norms, and culture. The aim of education is to specify more precisely what these desirable qualities are, e.g. critical thinking, the integrity of character, being creative, and so on (Peter, 1975, p. 1). In reality, educational activities have not been fully operational as a humanization process towards mature human beings growing with all their potential and abilities. Formal schools should emphasize the humanist learning process. Yet, they often imprison the learners as they fail to develop independence and merely force learners to memorize the books to pass the test. Excessive learning loads often drain student energy to reduce the chance to play and socialize. An unfortunate case reports in Bali Indonesia that a 
great number of homework assigned to the students causes a junior high school student in Bali to commit suicide (Nusa Bali, 2017).

Besides, the behavior of teachers and educators are still far from the spirit of education. Munificent violent behaviors occur in the school environment, either done by the teacher to student, student to teacher, or among the students themselves. Many cases of bullying still happen increasingly in several education levels. As the main force of the education reconnaissance, the school has failed to make a fun and child-friendly learning environment for students. Waters \& Mashburn (2017) states it is not only the student's cognitive skills that are affected but also the foundation for truly effective learning. It shows that the mission of education as a humanization process is still far from the expectation. Therefore, it is not astonishing that the culture of violence is still emotionally involved among Indonesian people. Ma'arif (2018, p. 104) states that the Indonesian educational system seems to follow the logic of pragmatism, although the school and the people of Indonesia are diverse and pluralistic, as well as have different problems and local knowledge. The formulation of the Indonesian education system is not based on a comprehensive picture of a country because many schools have a different kind of social model, culture, customs, ethnicity, race, language, character, and personality of its people. Yet this diversity should be viewed as an endowment that should be preserved, maintained, and developed so that it will inspire in the formation of the education system which will be applied in this country to overcome Indonesia's education problems.

Social studies are one of the subject matter in Indonesia schools expected to be an educational program for the embryonic of humanism values for citizens. Following the foundation of social studies on humanity and equality, the subject meant to provide a fundamental principle to determine ideal human character, which ultimately addresses the goal of the education process. Social studies expected to be one of the subjects that develop humanism in education. As a subject that is full of value, it should be the front line for developing the humanist values in society. It corresponds to the foundation of social studies on charity, provided by the fundamental ideas for determining the ideal human characteristics as the goal of the educational process. As a value-driven lesson, Social Studies has a mission to prepare students to be good citizens, to be a catalyst for constructive change, and to bring about a democratic society (Trianto, 2010; Nursid Sumatmaja, 2007; Nu'man Sumantri, 2001; Sapriya, 2009).

Budi Mulia 2 Junior High School is one of the schools with the energy of mind for building an educational environment for initialing humanism principles. The school philosophy emphasizes that each individual is unique, and because of that, each student has the specific ways and abilities that define them. The school makes honesty, respect, responsibility, and cleanliness as the pillars of humanistic education development. The school's motto is to study with joy in school. It means that students go to school with their happy feelings and hearts and when they are in school, they should be happy without being forced and without burden.

The classroom in Budi Mulia 2 Yogyakarta carries out a moving class system so that the class is given a special name that is adapted to some of the terms of the subjects studied in the class. 
The name is expected to provide an identity and self-pride for students who study in the classroom. The classrooms are named with unique concepts and theories such as Social, Cheng Ho, Pythagoras, Algebra, Script, Biodiversity, Photon, Avicena, Multimedia, Universal Class, Nobel Class, Srikandi, Gamelan, Pendopo, and Pringgodani. It is interesting to examine how teachers present humanistic Social Studies learning to encourage the growth of humanistic educational activities, as well as the student perceptions of humanistic Social Studies learning.

The various social problems faced by the nation of Indonesian are an accumulation $f$ increasingly complex issues in various aspects of life such as unemployment, poverty, and ignorance. The dynamics of multicultural society's life with high levels of difference and competition demand open, rational, and active citizens solve their social problems. The development of critical individuals who are responsible for social issues is the first step towards making society a democratic and independent social group. In that context, Social Studies become one of the most important school subjects that function as a means of cultivating the values of democracy and humanism. Ellis (1998, p. 15) states that Social Studies is fundamental as a school subject because of its commitment to the fulfilled person, the informed citizen, and the contributing individual.

Social science is a term used to refer to a field of study that includes several numbers of social sciences organized for school learning programs. Social science is a field of study with an interdisciplinary approach from the social sciences for the benefit of education and teaching. Social Studies is a part of school or college curriculum concerned with the study of social relations and the functioning of society, usually comprising courses in history, government, economics, civics, sociology, geography, and anthropology. National Commission on Social Studies (Savage, 1996, p. 9) defines Social Studies as follows:

Social studies are the integrated study of the social science and humanities to promote civic competence. Within the school program, social studies provide coordinated, systematic study drawing upon such disciplines as anthropology, archeology, economics, geography, history, law, philosophy, political science, psychology, religion, sociology, as well as appropriate content from the humanities, mathematics, and natural sciences. The primary purpose of social studies is to help young people develop the ability to make informed and reasoned decisions for the public good as citizens of a culturally diverse, democratic society in an interdependent world.

The objectives of Social Studies education are to educate and provide a basic set of skills for students so that they can develop themselves according to their talents, interests, abilities, and environment. This means that the subject educates, trains, and prepares learners to have critical thinking skills and be sensitive to social problems in their neighborhood to help solve them. Making the students as individuals that grow in humanistic ways is a noble task that requires creativity and the best professional skills from Social Studies teachers. Teachers must study the conditions around and be able to think critically to solve existing problems, emphasize the content and methods, and help students to become good citizens (Soemantri, 2001). To be thoughtful and effective citizens, students must understand how knowledge is 
constructed and how knowledge production is related to the location of knowledge producers in the social, political, and economic context of society. Banks (2007, p. 26) proposes five types of knowledge that can help educators conceptualize and teach about knowledge construction: (1) personal/cultural knowledge, (2) popular knowledge, (3) mainstream academic knowledge, (4) transformative academic knowledge, and (5) school knowledge. The Indonesian National Curriculum of 2013 provides guidance that requires Social Studies learning materials to contain social issues in which learners must understand and solve using multidimensional approaches, especially social sciences theories. Social Studies are presented in an integrated method with other social science disciplines. Concerning, the study is not separated in the boxes of existing disciplines. Integrated Social Studies is not just about teaching Social Studies materials by explaining them using an integrated approach (history, sociology, geography, economics, anthropology, and Civics), but it should be developed materials taught based on actual and real-life problems. Furthermore, Social Studies relates to values education as it concerns with general values such as liberty, justice, equality, honesty, consideration for others, individualism, human dignity, responsibility, and truthfulness. Jarolimek (1986, p. 34) states that if children are to socialize following these general values of society, they must be provided with examples of behavior explaining these values in action. That is, young people need to have encounters with the role models who can illustrate the values that society rewards and likes to see in its citizens. When these general values are internalized by the majority of citizens, then an orderly social life can take place.

Learning is a structured education activity that becomes the main pillar in school activities. Burns (1995, p.99) conceives learning as a relatively permanent change behavior is including both observable activity and internal processes such as thinking, attitudes, and emotions. Its motivation in this definition of learning considers that learning might not manifest itself in observable behavior until some times after the educational program has taken place. Learning activities thus become humane prototypes related to the transmission of knowledge and values. Humanist learning was developed in the United States in the 1960s as an application of the theory of humanist psychology developed by Karl Rogers and Abraham Maslow. Lei (Khatib, Sharen, \& Hamidi; 2013, p. 45) maintains that the humanist educations are characterized by learner-centeredness in which the aim is not merely developing the cognitive and linguistic capabilities of the learners, but also paying attention to the learners' emotions and feelings.

The estrangement of humanistic learning is an attempt at self-actualization as a representation of individual growth according to their abilities and potential. Juingna (2012, p. 33) states that self-actualization is the goal of education pursued by all of the humanism educators including Rogers. Rogers points out that the reason for people to learn is to satisfy the self-actualization needs. Self-actualization is a part of people's instinctive needs and it is the most important inner motility, as it has the power to promote the society. The aim of education is ultimately to promote self-actualization. The education ideal is to foster "self-actualize." It is emphasized that education aims are to foster open-minded, dynamic and adjustable people who know how to learn and continue to learn. Humanist education makes students become free human beings with independent- minds and free energy. Humanist 
education views learners as human beings who have different potential and characteristics. Willer (1975) points out the goal of humanistic education is the development of free, self-determining, self-renewing, and self-actualizing individuals. Negatively, genuinely free people do not believe that there are forces beyond their control which cause them to act and feel in certain ways. Positively, they enjoy making significant decisions about their own life and how they will spend it. Such a person is not threatened by the feelings and freedoms of others. He enjoys the independence of others and his becoming. Concerning the goal of education, humanistic education assumes that unconditioned human beings can learn independently through trial and error and without explaining the reward-punishment systems.

Understandably, some learners need certain assistance toward freedom. To help others become more self-actualizing and to cope with their freedom constitutes a major task of teachers who need to abandon their directing, correcting, controlling, and manipulating roles to become learning facilitators. Education as a process of humanizing of human beings must be placed proportionally and objectively as part of the natural actualization of nature. Therefore, freedom in selecting and developing potential is human nature (Dewantara, 2004; Freire, 1984). Such a critical pedagogy, combining classical idealism with postmodern disillusionment, will reconstitute the teachers, in keeping with their original humanistic ideals, as experts in 'training the young in the art of living' (Veugelers, 2011:37).

Kurtz stated that the principles of humanistic teaching were: (1) the need for education to be relevant to the needs of students and the problems of contemporary society; (2) the insistence that teachers should teach living students and not dead subject matter and the stress on creative learning; (3) the commitment to experimentation and innovation in educational curriculum and methods; (4) the view that students be given opportunity to participate and share in wider phases of school life; (5) the efforts to overcome dehumanizing and alienating forces that educational institutions seem to generate; (6) recognition that one of the most important aims of education should be development of critical intelligence and individual fulfillment (Guzetty, 1987).

The humanistic approach is concerned with making connections with people in other fields, with practice in schools, and with other human services. Often it becomes a study of the foundations of the helping professions as a whole and seeks to identify generic knowledge and competence underlying those professions. Thus, from a condition of health and hardiness, scholars and practitioners in the humanistic foundation's field reach out to colleagues in adjacent fields and adopt postures of openness, exploration, confidence, risk-taking, and innovation (Nash, 1984).

Humanistic education provides practical methods for engaging learners in self-directed and cooperative learning to promote self-esteem and supportive intergroup relation. It assumes that people want to learn and can be trusted to pursue their learning if based on their needs. Learning was an active process that necessitates involvement and participation. By definition, learning involves a change in perception that affects personal meaning rather than an accumulation of facts. Humanistic education integrates the cognitive and affective elements of learning. Humanistic educators believe that meaning is discovered through relating events 
to the self, and that long-lasting learning takes place when knowledge is connected to the affective state of the learner (Bell \& Schniedewind, 1987). That students and teachers are happier in humanistic schools and classrooms is not a sign of weakness. Neither does humanistic education require the surrender of traditional goals and objectives. Combs (1981, p. 449) explains this view by stating "I am not a humanist simply because I want to go around being nice to people. I am a humanist because I know that when I apply humanist thinking to problems in teaching, students learn anything better. They will be better writers, readers, mathematicians, farmers, physicians, truck-driver, whatever."

\section{Methodology}

The research was conducted by a survey method e.a systematic method for gathering information from (a sample of) individuals to describe the attributes of the larger population of which the individuals are members. The attributes attempt to describe the basic characteristics or experiences of large and small populations in the world.

The research took place at Budi Mulia 2 Junior High School, in Sleman, district of Yogyakarta Special Region, Indonesia. It is an international school, in which the students come from all over the country, as well as neighboring countries such: Malaysia, Singapore, and so on. The selection of the school as a research site is due to the implementation of humanist education in various fields of study, particularly referring to the curriculum and standards of international schools. The population of the study is the students of Budi Mulia 2 Junior High School, consisting of 380 students. The sampling technique used was proportional random sampling, which resulted in the students of Grade 7 and 8 taken as the research sample, with a total of 63 students as research sample. They were between 13-14 years old consisting of male and female. The sample of Indonesian citizens amounted 30 students, Malaysia 15, Singapore 15, another from India and China. Data collection techniques were conducted in two ways: interviews and questionnaires. Interviews were conducted with Social Studies teachers to explore information on how humanistic Social Studies learning strategies were conducted, objectives, and how the educational landforms. The questionnaire was used to provide a comprehensive picture of whether humanistic education has been implemented in school have adept encourage humanistic students.

Data analysis techniques are conducted by interactive data analysis that performs inappropriate: data reduction, display data, and conclusions drawing/verification (Miles \& Huberman, 1984: 21-13). For the questionnaire, the data analysis technique is done by using descriptive statistics, especially on the central tendency that seeks to give an idea of the students' perceptions and responses on Social Studies learning in schools. Therefore it is promising to determine whether humanistic Social Studies learning at the school helped students grow to be humanistic individuals and provide an environment in harmony with humanistic educational principles or not. 


\section{Findings and Discussion}

Budi Mulia 2 Yogyakarta accomplishes the nine years of basic education by continuing education that has been applied at the elementary school level. Educational paradigm was designed to developing students to be persons who have high self-esteem, integrity, creative, can express themselves according to their potential, sensitive to their environment, and have a strong foundation of faith and piety. Its school wants developing an educational program for the preparation of mature students on academic, psychological and social. The pattern of learning not only based on the universal knowledge and value of natural and social phenomena but also religiosity and morals. One aspect of humanistic learning in Budi Mulia 2 shows by student center learning in which students as subjects of learning who are given space to search for information to satisfy their curiosity while the teacher as a facilitator who helps students to understand the empirical world. Student-centered pedagogy is based upon the idea that student is the active agent and the teacher functions as a facilitator assisting students to construct their learning. Common pedagogical methods of instruction that are categorized as a student or learner-centered include case studies, cooperative learning, discussion, inquiry, role-play, simulations, and problem-based. Humanistic education provides practical methods for engaging learners in self-directed and cooperative learning and for promoting self-esteem and supportive inter-group relations (Bell \& Schniedewind, 1987).

Teachers encourage students to conduct independent investigations by providing academic tasks such as reading, interview, observing, and so on. For learning Social Studies, the teacher used several approaches such as cooperative learning, which aims to develop cooperation and the social skills of students. Its strategies required peer learning in their groups, in which students can share knowledge and help each other. The lack of restrictions in determining group members allows teachers to make students obtain adequate space to recognize all students in their classes. Humanism in Social Studies learning developed in other aspects is expected to become a place for nurturing humanistic values. On the other hand, the personal relationship between learners and teachers is well-established in all opportunities, both learning, and other educational activities. If they have a problem, students are not reluctant to consultation with their teacher anywhere.

Students call their teacher as Mister or Miss to eliminate the barrier between students and teachers. Furthermore, students are courageous in expressing their opinions and criticize teachers for better educational service. The learning of Social Studies conducted at Budi Mulia 2 has been carried out in a humanistic manner which is shown by the minor role of the teacher as a facilitator, who does not dictate the learning activities by dictating the materials. However, students as the subjects of learning discover information and knowledge independently guided by their teacher. The learning methods designed by teachers provide the freedom for students to not only elaborate learning materials independently, but also to have a responsibility in their groups. Some of the teaching methods applied by Social Studies teachers are presented in Table 1. 
Table 1. Several Methods for Social Studies Learning in Budi Mulia 2

\begin{tabular}{lll}
\hline Learning Methods & Media & Portfolio \\
\hline Discussion & Hand-outs & Report \\
Watching film or video & Films or video & Summary \\
Group presentation & Slides, pictures & Mind maps \\
Games & Cards & Cards \\
Problem-solving & Articles & Paper or chart \\
\hline
\end{tabular}

Table 1 shows the methods and learning media used by teachers have varied so learning activities become fun and meaningfull. Film screenings and photo displays provide opportunities for students to have a pleasant, hands-on experience. Social Studies teachers consider that students have competent in building a study-group independently. The division of the group is led by students appointed by friends for guiding and leading groups. It is a form of teacher appreciation of the ability and maturity of students as individuals who develop in the direction of emotional maturity. Goodlad (1985: 135) stated that the most successful classrooms may be those in which teachers succeed in creating commonly share goals and individuals cooperate in ensuring each person's success in achieving them. Cooperation between students in groups promotes trust and an attempt of improving social skills, especially in collaboration with others.

The activities of Social studies learning are not only carried out in the classroom, but also in other places such as libraries, parks, fields, and Social Studies laboratories. It is intended to provide a variety of learning atmosphere to make learning activities exciting. One of the outdoor learning activities designed by the teacher is an excursion study with the theme of Medang expedition that integrates various subjects, with Social Studies functioning as the core. Students who are accompanied by a supervising teacher explore some areas in Central Java, especially Dieng and Yogyakarta. They discovered archaeological evidence of ancient settlements and the physical environment in the form of vegetation, pets, and traditions. The activities lasted for a week and subsequently produced an academic report for enhancing their competence.

The facilities and physical infrastructure provided by Budi Mulia 2 have been adequate. A total of 10 classrooms with $720 \mathrm{~m}^{2}$ area is supported by other facilities such as laboratories, libraries, mosques, toilets, sports venues, and parks. Each class is equipped with lockers for students' storage, LCD projectors, and 25 student desks. Besides the school environment situated in the countryside, it makes Budi Mulia 2 a green and quiet school free from vehicle noise and other pollutants. With 25 students in each class, learning activities in the classroom become comfortable and pleasurable. Furthermore, the teacher's attention to students can be maximized and learning outcomes were excellent. The school guides students (student advisory), welcomes parents and facilitates students to participate in various field competitions. The following table gives an illustration of the level of student satisfaction with the services provided by the school: 


\section{Macrothink}

Table 2. Student Appreciation of Budi Mulia 2

\begin{tabular}{llcc}
\hline No & Item & Score & \% \\
\hline 1 & Opportunity & 171 & 90 \\
2 & Facilities & 165 & 87 \\
3 & Supporting & 163 & 86 \\
4 & Coordinating & 147 & 77 \\
5 & Coaching & 161 & 85 \\
\hline
\end{tabular}

Table 2 provides information that students of Budi Mulia 2 have a positive appreciation for school facilities and supports for progress and development. Adequate physical facilities help them develop their capacity and ability. The green, cool and beautiful environment allows students to interact and communicate with each other compassionately. In addition to motivating students to excellence in all aspects, the school strives to coordinate with parents in providing adequate coaching and guidance. Intensive communication between school and parents makes education activities work by well. Facilitation of freedom and learning is best accomplished by those teachers themselves who are learners and who are thereby worthy of student trust. Individuals become free learners under the authoritarian eye of an instructor supplying single directions, unquestionable answers, and impersonal reinforcement (Willers, 1975: 42).

Teachers of Budi Mulia 2 have a good performance on the carrying-out of educational tasks. Also, they have sufficient skills, competencies, and appropriate educational qualifications. Their competence and qualifications have a significant impact on humanistic learning since the teacher is the conductor with a central role in learning. As mature individuals, teachers act as the student coaches to establish their identity as humanist and democratic citizens. This is important and therefore requires good competencies and qualifications to be able to transmit humanism values in the classroom. Rogers (Guzetti, 1987: 26) stated:

I have found from experience that to stress the value of being real, of being one's feelings, is taken by some as a license to pass judgments on others, to project on others all the feelings which one should be "owning." Nothing could be further from my meaning. The achievement of realness is most difficult, and even when one wishes to be truly genuine, it occurs but rarely.

The description of teacher performance of Budi Mulia 2 on educational activities is described in the following table: 


\section{Macrothink}

Table 3. Teacher Performance of Budi Mulia 2

\begin{tabular}{rlcc}
\hline No & Item & Score & \% \\
\hline 1 & Friendliness & 161 & 85 \\
2 & Teaching ability & 170 & 89 \\
3 & Supporting and motivating & 157 & 83 \\
4 & Appreciation & 154 & 81 \\
5 & Discipline & 161 & 85 \\
\hline
\end{tabular}

Table 3 shows that students of Budi Mulia 2 are satisfied with the teacher's performance in carrying out their duties. The egalitarianism and familiarity make them sincere in addressing problems. The willingness of the teachers to appreciate students and consider them as developing personal qualities provides adequate space for students' courage to express their opinions and show their ability in public. The primary motivation of man is by an unlearned, inner drive toward personal belief in one's worth through which we develop and retain a sense of our uniqueness, integrity, and humanity. Because humanistic educators value the emotional and trust the rational aspects of humanity, they have recognized the essential role of feeling in the process of learning (Willers, 1975: 41).

\section{Conclusion}

Social studies learning at Budi Mulia 2 has been found to implement humanistic learning, as shown by the use of student-oriented learning strategy and group learning system, as well as egalitarianism in communication between teacher and student. Learning activities designed by teachers provide space for students to express their opinions and ideas. Also, it increases students' motivation to learn, read, and collect information to be delivered in front of their teacher and friends. The school's support for humanistic education is shown by the availability of various supporting facilities and programs to increase student capacities, such as laboratories, libraries, a park, and so on. Another supporting element is the provision of qualified and competent teachers. Teachers are motivated to continue developing student appreciation with various socio-cultural and economic backgrounds. Moreover, teachers have managed to provide positive supports to student interests and talents by assisting them with the required information.

\section{References}

Banks, J. (2007). Educating citizenship in a multicultural society. New York, USA: Teachers College Columbia University.

Bell, L., \& Schniedewind, N. (1987). Reflective minds/intentional hearts: joining humanistic education and critical theory for liberating education. The Journal of Education, 169(2), 55-77. https://doi.org/10.1177/002205748716900205 
Birsyada, M. I. (2016). Dasar-dasar pendidikan ilmu pengetahuan sosial (Suatu pendekatan teoritis dan praktis). Yogyakarta, Indonesia: Ombak.

Combs, A. (1981). Humanistic education: too tender for a tough world? The Phi Delta Kappan, 62(6), 446-449.

Dewantara, K. H. (2004). Pendidikan: buku 1A [Education: book 1]. Yogyakarta, Indonesia: Penerbit Tamansiswa.

Dewey, J. (1964). Democracy and education. New York, USA: the Macmillan Company.

Ellis, A. K. (1998). Teaching and learning elementary social studies. Boston, USA: Allyn \& Bacon.

Freire, P. (1984). Pedagogy of the oppressed. New York, USA: The Continuum International Publishing Group Inc.

Goodlad, J. A. (1985). A Place called school. in Beatrice \& Gross (Eds.). The great school debate, 135-158. New York, USA: Simon \& Schuster Inc.

Guzzetti, B. (1987). Humanism in the classroom. The Journal of Classroom Interaction, 22(2), 23-28.

Indonesian Educational System Act No. 20. (2003). Retrieved from https://kelembagaan.ristekdikti.go.id/

Juingna, D. U. (2012). Application of humanism theory in the teaching approach. Higher $\begin{array}{llll}\text { Education of Social } & \text { Science, } & 3(1), & 32-36 .\end{array}$ https://doi.org/10.3968/j.hess.1927024020120301

Khatib, M., Sarem, S. N., \& Hamidi, H. (2013). Humanistic education: concerns, implications andpplications. Journal of Language Teaching and Research, 4(1), 45-51. https://doi.org/10.4304/jltr.4.1.45-51

Knight, J., \& Albacht, P. G. (2007). The internationalization of higher education: motivations and realities. Journal of Studies in International Education, 11(3), 290-305. https://doi.org/10.1177/1028315307303542

Ma'arif, S. (2018). Education as a foundation of humanity: learning from the pedagogy of pesantren in Indonesia. Journal of Social Studies Education Research, 9(2), 104-123.

Miles, M. B., \& Huberman, A. M. (1984). Qualitative data analysis: A sourcebook of new methods. London, UK: Sage Publications.

Muhmidayeli. (2011). Filsafat pendidikan [Educational philosophy]. Bandung, Indonesia: RefikaAditama Press.

Nash, P. (1984). The humanistic foundations of education. Teacher Education Quarterly, 11(2), 53-59.

Nusa, B. (2017). Siswa SMP bunuh diri [A junior high school student's done suicide]. 
retrieved from https://www.nusabali.com/berita/10541/pelajar-smp-nekat-gantung-diri

Peter, R. S. (1975). Education and educated man. New York, USA: Simon \& Schuster Inc.

Purwanto, N. (2009). Evaluasi hasil belajar [Evaluation of learning outcome]. Yogyakarta, Indonesia: Pustaka Pelajar Press.

Savage, T. (1996). Effective teaching in elementary social studies. New Jersey, USA: Prentice Hall Inc.

Somantri, N. (2001). Menggagas pembaharauan pendidikan IPS [Initiating discussion on social studies education]. Bandung, Indonesia: Remaja Rosdakarya Inc.

Sukendar, A., Usman, H., \& Jabar, C. S. A. (2019). Teaching-loving-caring (asah-asih-asuh) and semi-military education on character education management. Cakrawala Pendidikan, 38(2), 293-305. https://doi.org/10.21831/cp.v38i2.24452

Waters, S., \& Mashburn, N. (2017). An investigation of middle school teachers' perceptions on bullying. Journal of Social Studies Education Research, 8(1), 1-34.

Willers, J. C. (1975). Humanistic education: concepts, criteria and criticism. Peabody Journal of Education, 53(1), 39-44. https://doi.org/10.1080/01619567509538047

\section{Copyright Disclaimer}

Copyright for this article is retained by the author(s), with first publication rights granted to the journal.

This is an open-access article distributed under the terms and conditions of the Creative Commons Attribution license (http://creativecommons.org/licenses/by/3.0/). 